Plant Production Science

http:/www.journals.zu.edu.eg/journalDisplay.aspx?Journalld=1\&queryType=Master

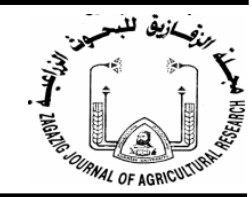

\title{
EFFECT OF NITROGEN FERTILIZATION AND ASCORBIC ACID ON GROWTH, ESSENTIAL OIL AND CHEMICAL COMPOSITION OF ROSEMARY PLANT
}

\author{
Amaal A.M. Heikal* and Samia S. Helmy \\ Ornamental Hort. Dept., Fac. Agric., Cairo Univ., Giza, Egypt
}

Received: 27/09/2017 ; Accepted: 12/12/2017

\begin{abstract}
A pot experiment was carried out during 2014 and 2015 seasons to study the effect of nitrogen fertilization $\left(0,1,2\right.$ and $\left.3 \mathrm{~g} \mathrm{~N}_{\text {pot }}{ }^{-1}\right)$ in the form of calcium nitrate $\mathrm{Ca}\left(\mathrm{NO}_{3}\right)_{2}(15.5 \% \mathrm{~N})$ and four spray levels with ascorbic acid $(0,50$ and $100 \mathrm{ppm})$ on growth, essential oil content and chemical composition of rosemary plant. Plastic pots of $25 \mathrm{~cm}$ diameter were used. Experimental treatments were laid out in a split plot design. Tow cuts were taken each season. Application of nitrogen up to $3 \mathrm{~g} \mathrm{~N} \mathrm{pot}^{-1}$ enhanced all studied growth parameters in terms of plant height, number of branches, fresh and dry weight of leaves as well as total chlorophyll, total carbohydrates, N, P, K contents. Essential oil content was enhanced by adding of nitrogen up to $2 \mathrm{~g} \mathrm{~N}$ pot $^{-1}$, thereafter more increase in nitrogen, significantly decreased essential oil content. Spraying rosemary plants with ascorbic acid up to $100 \mathrm{ppm}$, significantly enhanced plant height, branch number, fresh and dry weight of leaves and essential oil content as well as total chlorophyll, total carbohydrates, N, P and $\mathrm{K}$ contents. Rosemary plants fertilized with $3 \mathrm{~g} \mathrm{~N} \mathrm{pot}^{-1}$ and sprayed with $100 \mathrm{ppm}$ ascorbic acid gave the highest value of each of plant height, number of branches, fresh and dry weight of leaves, total chlorophyll and total carbohydrates, while the highest essential oil percentage was obtained from plants fertilized with $2 \mathrm{~g} \mathrm{~N}^{-1}$ and sprayed with $100 \mathrm{ppm}$ of ascorbic acid. Alpha-pinene, Eucalyptol, Linalool, Camphor, Endo-borneol and Cis-pinane were the major constituents of the essential oil profile, over all combinations of nitrogen and ascorbic acid levels in both cuts.
\end{abstract}

Key words: Rosmary, Rosmarinus officinalis L., nitrogen fertilization, ascorbic acid, growth, volatile oil.

\section{INTRODUCTION}

Rosemary (Rosmarinus officinalis L.) of the family Lamiaceae is one of the most valuable spices and medicinal plants that widely used around the world. Rosemary is native to the Mediterranean regions. Therefore, it well grows under Egyptian conditions and available all throughout the year. Implementation of naturally occurring antioxidants rather than synthetic antioxidants is a promising technology to increase the shelf life of foods. Rosemary organic residues after the distillation of leaves after manufacturing of essential oils was used to prevent lipid oxidation and color changes in meat products (Nieto et al., 2010 ; Banon et al., 2012). Rosemary extract, phenolics and essential

\footnotetext{
* Corresponding author: Tel. : +201001335841

E-mail address: amaalhiekal@gmail.com
}

oil, stimulates blood circulation and used as an antibacterial, antifungal, antiviral and anticancer agents (Oluwatuyi et al., 2004; Moreno et al., 2006; Sharabani et al., 2006; Cheung and Tai, 2007; Genena et al., 2008; Martínez et al., 2009; Yi and Wetzstein, 2010; Jiang et al., 2011; Moghtader et al., 2011; Tsai et al., 2011).

Herbage yield and essential oils production of aromatic and medicinal plants are influenced by many agricultural practices, including, fertilization and harvesting time (Min et al., 2005; Stutte, 2006; Badawy et al., 2009; SaidAl Ahl et al., 2009). Plant nutrition is one of the most important factors that increase plant production. Nitrogen is most recognized in plants for its presence in the structure of the 
protein molecule. In addition, nitrogen is found in molecules of purines and pyrimidines which represent the basic construction units for the nucleic acids. Nitrogen fertilization has been reported to increase herbage yield and essential oil production in Thymus vulgaris (Baranauskienne et al., 2003). Increasing $\mathrm{N}$ rates up to $1.2 \mathrm{~g} / \mathrm{pot}(30 \mathrm{~cm}$ diameter) significantly increased herb fresh yield and essential oil content of Origanum vulgare (SaidAl Ahl et al., 2009). Puttanna et al. (2010) evaluated the yield of herb and essential oil content of rosemary under 5 cuttings and 3 nitrogen rates $(0,150$ and $300 \mathrm{~kg} \mathrm{~N} / \mathrm{ha})$. The yield of herb reached the highest value in the second cutting; thereafter it decreased in the next three cuttings. Herb yield and essential oil content were increased significantly by the application of $150 \mathrm{~kg} \mathrm{~N} / \mathrm{ha}$. Application of N increased the concentration of N, P and $\mathrm{K}$ in the herb. Miguel et al. (2007) determined essential oil and its compositions in the aerial parts of rosemary collected at different harvesting periods. Essential oil content varied significantly among different harvesting periods $(0.5-1.4 \%)$. Analysis of essential oil at each harvesting time revealed nineteenth compounds with myrcene as the main component (23.2 $-30.0 \%$ ) followed by $\alpha$-pinene $(11.8-16.5 \%)$ and 1,8-cineole $(8.6-$ $12.2 \%)$. Application of nitrogen to rosemary plants enhanced leaf area, fresh and dry yield of herbs (Singh and Wasnik, 2013).

Vitamins could be considered as bio-regulators compounds in which a little concentrations have a great effect on plant growth. Ascorbic acid (Vitamin C) is considered as a regulator of growth and development of plants due to its effect on cell division and differentiation as well as it is involved in a wide range of important functions such as antioxidant defense, cofactor for several enzymes activity, regulation of photosynthesis processes and many physiological processes in plants (Smirnoff and Wheeler, 2000; Blokhina et al., 2003; Farooq et al., 2013; Zhang, 2013). Ascorbic acid is product of D-glucose metabolism which affects some nutritional cycles activity in higher plants and plays an important role in the electron transport system (El-Kobisy et al., 2005). Foliar application of ascorbic acid at different concentrations that ranges between $0.0 \mathrm{ppm}$ and $100 \mathrm{ppm}$ to many medicinal and aromatic plants showed considerable increases in lemongrass Cymbopogon citratus leaves contents of total carbohydrates and nitrogen (Tarraf et al., 1999); sweet pepper leaves contents of N, P, and K (Talaat, 2003); vegetative growth traits, fresh and dry weights of Hibiscus rosa sineses plant organs and leaves contents of chlorophyll, carotenoids, soluble sugars, N, P and K (El-Quesni et al., 2009). Plant height, branch number, fresh and dry weights of plant, chlorophyll content and oil percentage of basil plant (Khalil et al., 2010). Plant height, number of branches and flower heads of fennel plant (Hendawy and Ezz ElDin, 2010). Fresh and dry weights of roots, leaves and shoots as well as chlorophyll content of summer savory plants (Nikee et al., 2014).

This study aimed to evaluate the effect of nitrogen fertilization and foliar spray ascorbic acid on plant biomass and essential oil content and their main constituents of Rosmarinus officinalis $\mathrm{L}$.

\section{MATERIALS AND METHODS}

\section{Experimental Procedures and Design}

During 2014 and 2015 seasons, a pot experiment was carried out at the Experimental Nursery of the Ornamental Horticulture Department, Faculty of Agriculture, Cairo University, Giza (30 01' 39.36"N latitude and $31^{\circ} 12^{\prime} 36.50^{\prime \prime}$ E Longitude) Egypt, to study the effect of individual and combined effects of four nitrogen levels $\left(0,1,2\right.$ and $\left.3 \mathrm{~g} \mathrm{~N}_{\text {pot }}{ }^{-1}\right)$ and foliar spray with three levels of ascorbic acid $(0$, 50 and $100 \mathrm{ppm}$ ) on growth, essential oil content and chemical composition of rosemary (Rosmarinus officinalis L.) plant. Analysis of the experimental soil in which the pots was filled during the two seasons showed that the soil textural class is loamy clay with $\mathrm{pH}(7.85$ and 7.12$)$, EC (1.36 and $1.54 \mathrm{ds} / \mathrm{m})$, organic matter (1.62 and 1.40\%), available N (18.24 and $22.50 \mathrm{ppm})$, available $\mathrm{P}$ (13.32 and $15.45 \mathrm{ppm})$ and available $\mathrm{K}$ (135 and $150 \mathrm{ppm}$ ) in the first and second seasons, respectively. Rooted cuttings seedlings (10-12 cm long) were obtained from a nursery of Al-Qanater Al-Kheireya, Kalyoubeya Governorate and transplanted into 
plastic pots of $25 \mathrm{~cm}$ diameter filled with a loamy clay soil on the first of March in the first and second seasons, respectively. Nitrogen was added in the form of calcium nitrate, $\mathrm{Ca}\left(\mathrm{NO}_{3}\right)_{2}$ $(15.5 \% \mathrm{~N})$ at different four splits $(20 \%, 30 \%$, $20 \%$ and $30 \%$ ). The first dose was added to pots at seedlings transplanting, the second dose was added one month after transplanting, the third dose was added four months after transplanting (immediately after the first cut) and the fourth dose was added one month after the first cut. Nitrogen was applied with irrigation water (fertigation) by dissolving each dose in $0.75 \mathrm{~L}$ of water. Rosemary plants were sprayed with different concentrations of ascorbic acid $(0,50$ and $100 \mathrm{ppm}$ ) four times; the first and the second were sprayed one month and two months after transplanting, respectively while the third and the fourth were sprayed one month and two months after the first cut, respectively. Spraying with tape water $(0 \mathrm{ppm})$ represents control treatment. Water supply to plants was done as recommended. Experimental treatments were laid out in split plot arrangement in a randomized complete block design with three replicates. Nitrogen levels were allocated to the main plots, while ascorbic acid levels were assigned as sub plot. Each level of sub plot was represented by six pots for each replicate.

\section{Experimental Measurements}

Two cuts were taken each season, the first cut was taken on the $1^{\text {st }}$ of July (4 months after transplanting), while the second cut was taken on $15^{\text {th }}$ of November (4.5 months after the first one) by cutting the herb of the plants at $10 \mathrm{~cm}$ above the soil surface. Vegetative growth traits in terms of plant height $(\mathrm{cm})$, number of branches per plant and fresh leaves weight $(\mathrm{g})$ per plant were determined at harvest of each cut. The fresh leaves were dried at $70^{\circ} \mathrm{C}$ for $48 \mathrm{hr}$., and the dry weight $(\mathrm{g})$ of leaves per plant was recorded. Total chlorophylls content was measured one month before every cutting using chlorophyll meter, model SPAD-502, which SPAD unit $=10 \mathrm{mg} / 100 \mathrm{~g}$ fresh weight of leaves (Netto et al., 2005). Essential oil content was determined according to British Pharmacopoeia (1963) by hydro distillation of $100 \mathrm{~g}$ air dried leaves for three hours. The essential oil percentage was estimated as follows: Essential oil $(\%)=$ (reading measured pipette/sample weight $\times 100$. The essential oil samples obtained from different treatments were dried over anhydrous sodium sulfate and were subjected to GC/MS analysis according to Adams (1995) to determine their main constituents at the Central Laboratory of Faculty of Agriculture, Cairo University. Total carbohydrates content was determined in homogenized samples $(0.2 \mathrm{~g})$ from dried leaves according to Dubois et al. (1956). Total nitrogen content was determined by the modified microKjeldahl method as described by AOAC (1990). Total phosphorus content was determined according to the method of Jackson (1967). Potassium was determined using Model SP 1900 atomic absorption spectrophotometer with a boiling air-acetylene burner and recorded read out (Issac and Kerber, 1971). Essential oil constituents and chemical composition of rosemary plant were determined at the first and second cuts in samples collected across the two seasons.

\section{Statistical Analysis}

Data recorded on vegetative growth traits, essential oil content and total chlorophylls were analyzed using analysis of variance based on a split-plot arrangement in a randomized complete block design according to procedures outlined by Gomez and Gomez (1984) using MSTAT-C computer package (Freed et al., 1989). Treatment mean comparisons were performed using least significant difference (LSD) at 5\% level of probability.

\section{RESULTS AND DISCUSSION}

\section{Vegetative Growth Traits}

Nitrogen fertilization exhibited significant effect on growth traits in terms of plant height, number of branches, fresh and dry weights of leaves in the first and second cuts and over cuts during the two seasons (Tables 1, 2, 3 and 4). Nitrogen fertilization enhanced all studied growth traits up to $3 \mathrm{~g} \mathrm{~N} \mathrm{p}^{-1}$ at both cuts during the two seasons. The increasing in plant height is mainly due to the role of $\mathrm{N}$ in stimulating the 
Table 1. Effect of nitrogen fertilization, ascorbic acid and their interaction on plant height of rosemary plant at the first and second cuts during 2014 and 2015 seasons

\begin{tabular}{|c|c|c|c|c|c|c|c|}
\hline \multirow{2}{*}{$\begin{array}{c}\text { Nitrogen } \\
\text { (g/pot) } \\
\text { (N) }\end{array}$} & \multirow{2}{*}{$\begin{array}{l}\text { Ascorbic acid } \\
\text { (ppm) } \\
\text { (A) }\end{array}$} & \multicolumn{3}{|c|}{2014 season } & \multicolumn{3}{|c|}{2015 season } \\
\hline & & $1^{\text {st }}$ cut & $2^{\text {nd }}$ cut & Mean & $1^{\text {st }}$ cut & $2^{\text {nd }}$ cut & Mean \\
\hline \multirow{3}{*}{$\mathbf{0}$} & $\mathbf{0}$ & 53.44 & 42.22 & 50.33 & 53.50 & 43.50 & 51.00 \\
\hline & 50 & 59.00 & 50.45 & 57.22 & 63.34 & 53.67 & 61.01 \\
\hline & 100 & 70.66 & 58.33 & 67.00 & 71.33 & 61.17 & 68.75 \\
\hline \multirow[t]{2}{*}{ Mean } & & 61.03 & 50.33 & 58.18 & 62.72 & 52.78 & 60.25 \\
\hline & $\mathbf{0}$ & 61.22 & 50.67 & 58.45 & 62.00 & 52.00 & 59.50 \\
\hline \multirow[t]{2}{*}{1} & 50 & 66.22 & 57.50 & 64.36 & 69.83 & 60.25 & 67.54 \\
\hline & 100 & 73.00 & 60.67 & 69.33 & 74.00 & 64.00 & 71.50 \\
\hline \multirow[t]{2}{*}{ Mean } & & 66.81 & 56.28 & 64.05 & 68.61 & 58.75 & 66.18 \\
\hline & $\mathbf{0}$ & 76.78 & 62.33 & 72.06 & 77.17 & 63.50 & 72.84 \\
\hline \multirow[t]{2}{*}{2} & 50 & 81.00 & 66.33 & 76.17 & 82.50 & 69.00 & 78.25 \\
\hline & 100 & 86.22 & 70.11 & 80.67 & 87.34 & 71.33 & 81.84 \\
\hline \multirow[t]{2}{*}{ Mean } & & 81.33 & 66.26 & 76.30 & 82.34 & 67.94 & 77.64 \\
\hline & $\mathbf{0}$ & 87.78 & 69.33 & 81.06 & 85.83 & 72.00 & 81.42 \\
\hline \multirow[t]{2}{*}{3} & 50 & 89.22 & 71.00 & 82.61 & 88.67 & 71.84 & 82.75 \\
\hline & 100 & 87.89 & 73.33 & 83.11 & 87.50 & 74.00 & 83.25 \\
\hline Mean & & 88.30 & 71.22 & 82.26 & 87.33 & 72.61 & 82.47 \\
\hline \multirow[t]{2}{*}{ Grand mean } & & 74.37 & 61.02 & 70.20 & 75.25 & 63.02 & 71.64 \\
\hline & $\mathbf{0}$ & 69.81 & 56.14 & 65.48 & 69.63 & 57.75 & 66.19 \\
\hline \multirow[t]{2}{*}{ Mean of ascorbic } & 50 & 73.86 & 61.32 & 70.09 & 76.09 & 63.69 & 72.39 \\
\hline & 100 & 79.44 & 65.61 & 75.03 & 80.04 & 67.63 & 76.34 \\
\hline \multicolumn{8}{|l|}{ LSD at $5 \%$} \\
\hline Nitrogen $(\mathbf{N})$ & & 2.77 & 2.17 & 1.56 & 2.34 & 1.90 & 1.34 \\
\hline Ascorbic acid (A) & & 2.55 & 2.19 & 1.62 & 1.48 & 1.38 & 0.97 \\
\hline $\mathbf{N} \times \mathbf{A}$ & & 4.09 & 3.39 & 2.23 & 2.96 & 2.75 & 1.94 \\
\hline
\end{tabular}


Zagazig J. Agric. Res., Vol. 45 No. (1) 2018

Table 2. Effect of nitrogen fertilization ascorbic acid and their interaction on branch number/ plant of rosemary plant at the first and second cuts during 2014 and 2015 seasons

\begin{tabular}{|c|c|c|c|c|c|c|c|}
\hline \multirow{2}{*}{$\begin{array}{l}\text { Nitrogen } \\
\text { (g/pot) } \\
(\mathbf{N})\end{array}$} & \multirow{2}{*}{$\begin{array}{l}\text { Ascorbic acid } \\
\text { (ppm) } \\
\text { (A) }\end{array}$} & \multicolumn{3}{|c|}{2014 season } & \multicolumn{3}{|c|}{2015 season } \\
\hline & & $1^{\text {st }}$ cut & $2^{\text {nd }}$ cut & Mean & $1^{\text {st }}$ cut & $2^{\text {nd }}$ cut & Mean \\
\hline \multirow{3}{*}{$\mathbf{0}$} & $\mathbf{0}$ & 5.89 & 9.33 & 7.61 & 6.84 & 10.17 & 8.51 \\
\hline & 50 & 7.89 & 11.00 & 9.44 & 9.17 & 11.84 & 10.50 \\
\hline & 100 & 8.78 & 12.72 & 10.75 & 9.84 & 12.67 & 11.25 \\
\hline \multirow[t]{2}{*}{ Mean } & & 7.52 & 11.02 & 9.27 & 8.62 & 11.56 & 10.09 \\
\hline & $\mathbf{0}$ & 6.11 & 10.11 & 8.11 & 7.17 & 11.67 & 9.42 \\
\hline \multirow[t]{2}{*}{1} & 50 & 8.44 & 11.83 & 10.14 & 9.67 & 12.00 & 10.84 \\
\hline & 100 & 9.47 & 13.00 & 11.23 & 10.50 & 12.75 & 11.63 \\
\hline \multirow[t]{2}{*}{ Mean } & & 8.01 & 11.65 & 9.83 & 9.11 & 12.14 & 10.63 \\
\hline & $\mathbf{0}$ & 8.07 & 11.67 & 9.87 & 9.10 & 12.00 & 10.55 \\
\hline \multirow[t]{2}{*}{2} & 50 & 9.33 & 12.00 & 10.67 & 10.00 & 13.00 & 11.50 \\
\hline & 100 & 10.50 & 13.17 & 11.83 & 12.09 & 13.75 & 12.92 \\
\hline \multirow[t]{2}{*}{ Mean } & & 9.30 & 12.28 & 10.79 & 10.40 & 12.92 & 11.66 \\
\hline & $\mathbf{0}$ & 8.53 & 11.89 & 10.21 & 9.80 & 12.83 & 11.32 \\
\hline \multirow[t]{2}{*}{3} & 50 & 10.00 & 13.11 & 11.56 & 10.50 & 13.50 & 12.00 \\
\hline & 100 & 11.18 & 14.00 & 12.59 & 12.27 & 14.00 & 13.14 \\
\hline Mean & & 9.90 & 13.00 & 11.45 & 10.86 & 13.44 & 12.15 \\
\hline \multirow[t]{2}{*}{ Grand mean } & & 8.68 & 11.99 & 10.33 & 9.75 & 12.51 & 11.13 \\
\hline & $\mathbf{0}$ & 7.15 & 10.75 & 8.95 & 8.23 & 11.67 & 9.95 \\
\hline \multirow[t]{2}{*}{ Mean of ascorbic } & 50 & 8.92 & 11.99 & 10.45 & 9.84 & 12.58 & 11.21 \\
\hline & 100 & 9.98 & 13.22 & 11.60 & 11.18 & 13.29 & 12.23 \\
\hline \multicolumn{8}{|l|}{ LSD at $5 \%$} \\
\hline Nitrogen $(\mathbf{N})$ & & 0.30 & 0.85 & 0.40 & 0.15 & 0.63 & 0.29 \\
\hline Ascorbic acid (A) & & 0.79 & 0.53 & 0.46 & 0.62 & 0.39 & 0.52 \\
\hline $\mathbf{N} \times \mathbf{A}$ & & NS & NS & NS & 0.85 & 0.77 & 1.04 \\
\hline
\end{tabular}


Table 3. Effect of nitrogen fertilization, ascorbic acid and their interaction on fresh leaves weight/plant of rosemary plant at the first and second cuts during 2014 and 2015 seasons

\begin{tabular}{|c|c|c|c|c|c|c|c|}
\hline \multirow{2}{*}{$\begin{array}{c}\text { Nitrogen } \\
\text { (g/pot) } \\
(\mathrm{N})\end{array}$} & \multirow{2}{*}{$\begin{array}{c}\text { Ascorbic acid } \\
\text { (ppm) } \\
\text { (A) }\end{array}$} & \multicolumn{3}{|c|}{2014 season } & \multicolumn{3}{|c|}{2015 season } \\
\hline & & $1^{\text {st }}$ cut & $2^{\text {nd }}$ cut & Mean & $1^{\text {st }}$ cut & $2^{\text {nd }}$ cut & Mean \\
\hline \multirow{3}{*}{$\mathbf{0}$} & $\mathbf{0}$ & 45.52 & 56.08 & 50.8 & 53.7 & 61.85 & 57.78 \\
\hline & 50 & 56.63 & 73.62 & 65.12 & 64.47 & 80.18 & 72.32 \\
\hline & 100 & 75.68 & 80.82 & 78.25 & 76.19 & 83.91 & 80.05 \\
\hline \multirow[t]{2}{*}{ Mean } & & 59.28 & 70.17 & 64.73 & 64.79 & 75.31 & 70.05 \\
\hline & $\mathbf{0}$ & 52.11 & 66.88 & 59.5 & 59.17 & 69.54 & 64.35 \\
\hline \multirow[t]{2}{*}{1} & 50 & 61.49 & 75.49 & 68.49 & 67.46 & 76.73 & 72.09 \\
\hline & 100 & 72.71 & 83.27 & 77.99 & 75.06 & 88.02 & 81.54 \\
\hline \multirow[t]{2}{*}{ Mean } & & 62.10 & 75.21 & 68.66 & 67.23 & 78.10 & 72.66 \\
\hline & $\mathbf{0}$ & 68.11 & 80.52 & 74.31 & 73.83 & 84.28 & 79.06 \\
\hline \multirow[t]{2}{*}{2} & 50 & 74.8 & 86.83 & 80.82 & 83.39 & 90.63 & 87.01 \\
\hline & 100 & 88.69 & 108.56 & 98.63 & 95.25 & 110.7 & 102.97 \\
\hline \multirow[t]{2}{*}{ Mean } & & 77.20 & 91.97 & 84.59 & 84.16 & 95.20 & 89.68 \\
\hline & $\mathbf{0}$ & 77.85 & 85.89 & 81.87 & 84.69 & 88.51 & 86.6 \\
\hline \multirow[t]{2}{*}{3} & 50 & 85.87 & 102.32 & 94.09 & 94.2 & 106.32 & 100.26 \\
\hline & 100 & 92.94 & 114.9 & 103.92 & 98.45 & 118.53 & 108.49 \\
\hline Mean & & 85.55 & 101.04 & 93.3 & 92.44 & 104.45 & 98.45 \\
\hline \multirow[t]{2}{*}{ Grand mean } & & 71.03 & 84.60 & 77.82 & 77.15 & 88.27 & 82.71 \\
\hline & $\mathbf{0}$ & 60.9 & 72.34 & 66.62 & 67.85 & 76.04 & 71.95 \\
\hline \multirow[t]{2}{*}{ Mean of ascorbic } & 50 & 69.7 & 84.57 & 77.13 & 77.38 & 88.46 & 82.92 \\
\hline & 100 & 82.51 & 96.89 & 89.7 & 86.24 & 100.29 & 93.26 \\
\hline \multicolumn{8}{|l|}{ LSD at $5 \%$} \\
\hline Nitrogen $(\mathbf{N})$ & & 6.54 & 5.28 & 4.47 & 5.34 & 3.98 & 2.96 \\
\hline Ascorbic acid (A) & & 4.62 & 3.67 & 3.22 & 3.92 & 3.01 & 2.37 \\
\hline $\mathbf{N} \times \mathbf{A}$ & & 7.24 & 6.34 & 5.45 & 6.83 & 5.02 & 4.75 \\
\hline
\end{tabular}


Zagazig J. Agric. Res., Vol. 45 No. (1) 2018

Table 4. Effect of nitrogen fertilization and ascorbic acid on dry leaves weight/plant of rosemary plant at two cuts during 2014 and 2015 seasons

\begin{tabular}{|c|c|c|c|c|c|c|c|}
\hline \multirow{2}{*}{$\begin{array}{l}\text { Nitrogen } \\
\text { (g/pot) } \\
\text { (N) }\end{array}$} & \multirow{2}{*}{$\begin{array}{l}\text { Ascorbic acid } \\
\text { (ppm) } \\
\text { (A) }\end{array}$} & \multicolumn{3}{|c|}{2014 season } & \multicolumn{3}{|c|}{2015 season } \\
\hline & & $1^{\text {st }}$ cut & $2^{\text {nd }}$ cut & Mean & $1^{\text {st }}$ cut & $2^{\text {nd }}$ cut & Mean \\
\hline \multirow{3}{*}{$\mathbf{0}$} & $\mathbf{0}$ & 12.59 & 15.78 & 14.19 & 15.12 & 17.33 & 16.23 \\
\hline & 50 & 17.19 & 21.62 & 19.41 & 19.58 & 23.55 & 21.57 \\
\hline & 100 & 22.92 & 24.46 & 23.69 & 23.94 & 25.25 & 24.6 \\
\hline \multirow[t]{2}{*}{ Mean } & & 17.57 & 20.62 & 19.09 & 19.55 & 22.05 & 20.8 \\
\hline & $\mathbf{0}$ & 15.52 & 19.84 & 17.68 & 17.59 & 20.56 & 19.08 \\
\hline \multirow[t]{2}{*}{1} & 50 & 18.78 & 22.81 & 20.8 & 20.86 & 23.25 & 22.06 \\
\hline & 100 & 22.04 & 25.39 & 23.72 & 23.87 & 26.69 & 25.28 \\
\hline \multirow[t]{2}{*}{ Mean } & & 18.78 & 22.68 & 20.73 & 20.77 & 23.5 & 22.14 \\
\hline & $\mathbf{0}$ & 21.97 & 25.45 & 23.71 & 23.71 & 26.69 & 25.2 \\
\hline \multirow[t]{2}{*}{2} & 50 & 23.18 & 26.62 & 24.9 & 25.87 & 27.35 & 26.61 \\
\hline & 100 & 30.18 & 35.24 & 32.71 & 32.34 & 35.47 & 33.91 \\
\hline \multirow[t]{2}{*}{ Mean } & & 25.11 & 29.1 & 27.11 & 27.31 & 29.84 & 28.57 \\
\hline & $\mathbf{0}$ & 26.22 & 26.33 & 26.27 & 28.48 & 27.25 & 27.86 \\
\hline \multirow[t]{2}{*}{3} & 50 & 27.89 & 31.36 & 29.63 & 30.61 & 32.53 & 31.57 \\
\hline & 100 & 29.64 & 35.92 & 32.78 & 31.3 & 37.15 & 34.23 \\
\hline Mean & & 27.92 & 31.2 & 29.56 & 30.13 & 32.31 & 31.22 \\
\hline \multirow[t]{2}{*}{ Grand mean } & & $22.34^{\mathrm{a}}$ & $25.90^{\mathrm{a}^{+}}$ & 24.12 & $24.44^{\mathrm{a}}$ & $26.92^{\mathrm{a}}$ & 25.68 \\
\hline & $\mathbf{0}$ & 19.08 & 21.85 & 20.46 & 21.23 & 22.96 & 22.09 \\
\hline \multirow[t]{2}{*}{ Mean of ascorbic } & 50 & 21.76 & 25.6 & 23.68 & 24.23 & 26.67 & 25.45 \\
\hline & 100 & 26.2 & 30.25 & 28.23 & 27.86 & 31.14 & 29.5 \\
\hline \multicolumn{8}{|l|}{ LSD at $5 \%$} \\
\hline Nitrogen $(\mathbf{N})$ & & 3.18 & 1.58 & 1.58 & 1.95 & 1.09 & 0.99 \\
\hline Ascorbic acid (A) & & 2.02 & 1.1 & 1.1 & 1.44 & 0.86 & 0.8 \\
\hline $\mathbf{N} \times \mathbf{A}$ & & 4.03 & 2.2 & 2.21 & 2.87 & 1.72 & 1.61 \\
\hline
\end{tabular}


meristematic growth activity which contributes to the increase in number of cells in additions to cell enlargement. The increases in the number of branches/plant led to an increase in the plant biomass represented here in the yield of plant leaves. In the first season, raising $\mathrm{N}$ level from 0 to 1,2 and $3 \mathrm{~g} \mathrm{~N}_{\text {pot }}{ }^{-1}$ increased fresh yield of leaves (Table 3 ) by about $4.76 \%, 30.23 \%$ and $44.32 \%$, respectively in the first cut, corresponding to $7.18 \%, 31.07 \%$ and $43.99 \%$, respectively in the second cut. In the second season, the increasing in fresh yield of leaves amounted to $3.77 \%, 29.90 \%$ and $42.68 \%$, respectively in the first cut, corresponding to $3.70 \%, 26.41 \%$ and $38.69 \%$, respectively in the second cut. Dry weight of leaves in relation to raising $\mathrm{N}$ level followed the same trend as fresh weight of leaves at each cut during the two seasons. Similar findings were reported by Baranauskienne et al. (2003) on thyme plant and Singh and Wasnik (2013) on rosemary plant.

Foliar application of ascorbic acid either at $50 \mathrm{ppm}$ or $100 \mathrm{ppm}$ significantly increased $(\mathrm{P}<0.05)$ all studied growth traits as compared to control treatment (spraying with tap water) at each cut and across cuts during the two seasons (Tables 1, 2, 3 and 4). Spraying rosemary plants with ascorbic acid significantly enhanced plant height, branch number, fresh and dry weight of leaves up to $100 \mathrm{ppm}$ at both cuts during the two seasons. In the first season, the yield of fresh leaves plant ${ }^{-1}$ (Table 3) significantly increased by about $14.45 \%$ and $35.48 \%$ at the first cut when ascorbic acid concentrations increased from 0 to 50 and $100 \mathrm{ppm}$, respectively, corresponding to $16.91 \%$ and $33.94 \%$, respectively at the second cut. In the second season, the increasing in fresh yield of leaves amounted to $14.05 \%$ and $27.10 \%$, respectively at the first cut, corresponding to $16.33 \%$ and $31.89 \%$, respectively at the second cut. The yield of dry leaves plant $^{-1}$ in relation to ascorbic acid followed the same trend as fresh yield of leaves.

The increase in rosemary plant biomass due to spraying with ascorbic acid confirms the role of vitamin $\mathrm{C}$ in regulation of photosynthesis processes and growth activation (Zhang, 2013; Farooq et al., 2013). The obtained results are in agreement with those reported by El-Quesni $\boldsymbol{e t}$ al. (2009); Hendawy and Ezz El-Din (2010); Khalil et al. (2010) and Nikee et al. (2014). The highest values of each plant height and branch number was measured at the first and second cuts, respectively in both seasons. Although, the yield of fresh leaves plant ${ }^{-1}$ (Table 3) obtained from the second cut was significantly higher than that obtained from the first one in both seasons, the difference between the two cuts in the dry leaves yield (Table 4) was insignificant due to the difference in moisture content of plants harvested at the two cuts. The interaction between nitrogen and ascorbic acid levels was significant for all studied growth traits at both cuts and across two cuts during the two seasons, except for branch number plant ${ }^{-1}$ that was affected with interaction only in the second season. Rosemary plants fertilized with $3 \mathrm{~g} \mathrm{~N} \mathrm{pot}^{-1}$ and spray it with 100 ppm ascorbic acid gave the highest values of plant height, number of branches, fresh and dry weight of leaves (Tables 1, 2, 3 and 4) across the two cuts in both seasons.

\section{Essential Oil (\%) and its Compositions}

\section{Essential oil percentage}

Essential oil percentage in the dried rosemary leaves (Table 5) was enhanced by adding of nitrogen up to $2 \mathrm{~g} \mathrm{~N} \mathrm{pot}^{-1}$ in both cuts and over cuts in both seasons, thereafter more increase in nitrogen, significantly decreased $(\mathrm{P}<0.05)$ essential oil (\%). The adverse effect of excessive nitrogen, fertilization on essential oil (\%) was reported by Puttanna et al. (2010). The essential oil (\%) was significantly increased by foliar application of ascorbic acid at the levels of 50 and 100 ppm compared with control treatment at the two cuts and over cuts in both seasons. The highest and significant essential oil percentage was obtained from leaves of plants sprayed with $100 \mathrm{ppm}$. Essential oil obtained from the second cut was significantly higher than that obtained from the first cut in both seasons. The positive effect of ascorbic acid on essential oil content was reported by Khalil $\boldsymbol{e t}$ al. (2010). The interaction between nitrogen and 
Zagazig J. Agric. Res., Vol. 45 No. (1) 2018

Table 5. Effect of nitrogen fertilization, ascorbic acid and their interaction on essential oil percentage of the dried rosemary leaves at the first and second cuts during 2014 and 2015 seasons

\begin{tabular}{|c|c|c|c|c|c|c|c|}
\hline \multirow{2}{*}{$\begin{array}{c}\text { Nitrogen } \\
\text { (g/pot) } \\
(\mathrm{N})\end{array}$} & \multirow{2}{*}{$\begin{array}{l}\text { Ascorbic acid } \\
\text { (ppm) } \\
\text { (A) }\end{array}$} & \multicolumn{3}{|c|}{2014 season } & \multicolumn{3}{|c|}{2015 season } \\
\hline & & $1^{\text {st }}$ cut & $2^{\text {nd }}$ cut & Mean & $1^{\text {st }}$ cut & $2^{\text {nd }}$ cut & Mean \\
\hline \multirow{3}{*}{ 0 } & $\mathbf{0}$ & 0.25 & 0.31 & 0.28 & 0.27 & 0.33 & 0.30 \\
\hline & 50 & 0.31 & 0.42 & 0.36 & 0.32 & 0.45 & 0.39 \\
\hline & 100 & 0.38 & 0.58 & 0.48 & 0.40 & 0.62 & 0.51 \\
\hline \multirow[t]{2}{*}{ Mean } & & 0.31 & 0.44 & 0.37 & 0.33 & 0.47 & 0.40 \\
\hline & 0 & 0.29 & 0.36 & 0.33 & 0.30 & 0.39 & 0.35 \\
\hline \multirow[t]{2}{*}{1} & 50 & 0.33 & 0.47 & 0.40 & 0.37 & 0.47 & 0.42 \\
\hline & 100 & 0.36 & 0.59 & 0.47 & 0.39 & 0.63 & 0.51 \\
\hline \multirow[t]{2}{*}{ Mean } & & 0.33 & 0.47 & 0.40 & 0.35 & 0.50 & 0.43 \\
\hline & $\mathbf{0}$ & 0.35 & 0.43 & 0.39 & 0.38 & 0.44 & 0.41 \\
\hline \multirow[t]{2}{*}{2} & 50 & 0.37 & 0.48 & 0.43 & 0.40 & 0.50 & 0.45 \\
\hline & 100 & 0.42 & 0.68 & 0.55 & 0.42 & 0.72 & 0.57 \\
\hline \multirow[t]{2}{*}{ Mean } & & 0.38 & 0.53 & 0.46 & 0.40 & 0.55 & 0.48 \\
\hline & $\mathbf{0}$ & 0.29 & 0.35 & 0.32 & 0.32 & 0.36 & 0.34 \\
\hline \multirow[t]{2}{*}{3} & 50 & 0.31 & 0.38 & 0.35 & 0.33 & 0.41 & 0.37 \\
\hline & 100 & 0.34 & 0.42 & 0.38 & 0.36 & 0.42 & 0.39 \\
\hline Mean & & 0.32 & 0.38 & 0.35 & 0.34 & 0.40 & 0.37 \\
\hline \multirow[t]{2}{*}{ Grand mean } & & 0.33 & 0.46 & 0.40 & 0.35 & 0.48 & 0.42 \\
\hline & $\mathbf{0}$ & 0.30 & 0.36 & 0.33 & 0.32 & 0.38 & 0.35 \\
\hline \multirow[t]{2}{*}{ Mean of ascorbic } & 50 & 0.33 & 0.44 & 0.38 & 0.36 & 0.46 & 0.41 \\
\hline & 100 & 0.38 & 0.57 & 0.47 & 0.39 & 0.60 & 0.49 \\
\hline \multicolumn{8}{|l|}{ LSD at $5 \%$} \\
\hline Nitrogen $(\mathbf{N})$ & & 0.04 & 0.05 & 0.02 & 0.02 & 0.05 & 0.03 \\
\hline Ascorbic acid (A) & & 0.03 & 0.03 & 0.02 & 0.01 & 0.03 & 0.02 \\
\hline $\mathbf{N} \times \mathbf{A}$ & & 0.05 & 0.05 & 0.04 & 0.02 & 0.05 & 0.04 \\
\hline
\end{tabular}


ascorbic acid levels was significant for leaves essential oil (\%) in both cuts and across two cuts during the two seasons. The highest essential oil percentage was obtained from leaves of plants fertilized with $2 \mathrm{~g} \mathrm{~N} \mathrm{pot}^{-1}$ and sprayed with 100 ppm of ascorbic acid.

\section{Essential oil composition}

The analysis of rosemary essential oil samples of different treatments of this experiment showed variability in both qualitative and quantitative of essential oil composition. Essential oil contained more than fifty components and the majority of these components found in the form of traces $(<0.5 \%)$. Twenty compounds, which account for more than $80 \%$ of essential oil constituents, are listed in Table 6. Nitrogen fertilization and ascorbic acid affected the chemical profile of essential oil samples from the two cuts. Six compounds (Alpha-pinene, Eucalyptol, Linalool, Camphor, Endo-borneol and Cis-pinane) accounted $59.72 \%, 59.95 \%, 55.77 \%$ and $59.41 \%$ under nitrogen levels of $0,1,2$ and $3 \mathrm{~g}^{p^{-1}}{ }^{-1}$, respectively at the first cut, corresponding to $55.30 \%, 55.02 \%, 53.75$ and $58.51 \%$, respectively at the second one. The previous six compounds accounted $57.42 \%, 59.34 \%$ and $59.38 \%$ of the essential oil components under ascorbic acid levels of 0,50 and $100 \mathrm{ppm}$, respectively in the first cut, corresponding to $54.54 \%, 56.36 \%$ and $56.04 \%$, respectively in the second one. The aforementioned compounds were the major constituents of the essential oil profile, over all combinations of nitrogen and ascorbic acid levels at both cuts.

\section{Total chlorophyll content}

Results presented in Table 7 show that application of nitrogen to rosemary plants significantly increased total chlorophyll readings taken at the two cuts in both seasons. Total chlorophyll increased gradually with increasing nitrogen level up to $3 \mathrm{~g} \mathrm{~N}_{\text {pot }}{ }^{-1}$. Spraying plants with ascorbic acid either at $50 \mathrm{ppm}$ or $100 \mathrm{ppm}$ significantly increased total chlorophyll content compared to control treatment in both cuts during the two seasons. The highest chlorophyll readings resulted from spraying plants with 100 ppm of ascorbic acid in both seasons. The role of ascorbic acid in enhancing chlorophyll content in leaves of different medicinal and aromatic plants was reported by El-Quesni $\boldsymbol{e t}$ al. (2009), Khalil et al. (2010) and Nikee et al. (2014). Total chlorophyll content was significantly affected by the interaction between nitrogen and ascorbic acid levels at the two cuts in both seasons. The highest total chlorophyll was recorded when plants sprayed with $100 \mathrm{ppm}$ of ascorbic acid and fertilized with 2 and /or $3 \mathrm{~g}$ $\mathrm{N}_{\text {pot }}{ }^{-1}$ at both seasons.

\section{Chemical constituents}

Results in Table 8 reveal that application of nitrogen fertilization up to $3 \mathrm{~g} \mathrm{~N}_{\text {pot }}{ }^{-1}$ increased total carbohydrates, N, P and K contents in herb of rosemary plants at the two cuts. Similar result was reported by Puttanna et al. (2010). Spraying plants with ascorbic acid either at 50 ppm or 100 ppm increased total carbohydrates, $\mathrm{N}, \mathrm{P}$ and $\mathrm{K}$ contents compared to control treatment at both cuts. The highest values of total carbohydrates (26.50 and 23.40\%), N (2.00 and $2.09 \%), \mathrm{P}(0.26$ and $0.31 \%)$ and $\mathrm{K}(1.72$ and $2.10 \%$ ) contents resulted from fertilized plants with $3 \mathrm{~g} \mathrm{~N}^{-1}$ and sprayed them with100 ppm of ascorbic acid at the first and second cuts, respectively. These results agreed with findings obtained by Tarraf et al. (1999) on lemongrass and Talaat (2003) on sweet pepper plants who found that total carbohydrates, $\mathrm{N}, \mathrm{P}$, and $\mathrm{K}$ in herb of lemongrass and sweet pepper were increased by application of ascorbic acid.

\section{Conclusion}

According to the results of this study on rosemary plant; it may be recommended that to obtain high herbage yield, the plants should be fertilized with $3 \mathrm{~g} \mathrm{~N} /$ pot and sprayed with 100 ppm of ascorbic acid. For obtaining high essential oil content, application of $2 \mathrm{~g} \mathrm{~N} /$ pot with $100 \mathrm{ppm}$ of ascorbic acid is recommended. 
Table 6. Chemical composition of rosemary essential oil as affected by nitrogen fertilization, ascorbic acid and their interaction

\begin{tabular}{|c|c|c|c|c|c|c|c|}
\hline \multirow[t]{4}{*}{ Compound } & \multirow{4}{*}{$\begin{array}{c}\mathbf{N} \\
(\mathrm{g} / \text { pot })\end{array}$} & \multicolumn{6}{|c|}{ Relative concentration of compound (\%) } \\
\hline & & \multicolumn{6}{|c|}{ Ascorbic acid (ppm) } \\
\hline & & \multicolumn{3}{|c|}{$1^{\text {st }}$ cut } & \multicolumn{3}{|c|}{$2^{\text {nd }}$ cut } \\
\hline & & $\mathbf{0}$ & 50 & 100 & $\mathbf{0}$ & 50 & 100 \\
\hline Alpha- pinene & & 8.44 & 6.37 & 9.61 & 5.99 & 9.10 & 8.80 \\
\hline Eucalyptol & & 10.20 & 10.95 & 9.84 & 9.01 & 9.51 & 9.75 \\
\hline Linalool & & 6.00 & 7.31 & 5.86 & 6.88 & 5.68 & 5.77 \\
\hline Camphor & & 11.99 & 15.67 & 13.42 & 12.55 & 11.86 & 12.44 \\
\hline Endo-borneol & & 10.99 & 11.69 & 10.15 & 11.42 & 10.54 & 10.90 \\
\hline Alpha- terpineol & & 3.03 & 3.46 & 2.56 & 2.53 & 2.30 & 3.04 \\
\hline Cis-pinane & & 9.49 & 11.18 & 9.99 & 7.56 & 9.21 & 8.93 \\
\hline Trans-caryophyllene & & 3.20 & 2.27 & 2.18 & 1.98 & 1.71 & 1.49 \\
\hline Camphene & & 2.45 & 1.64 & 3.14 & 1.47 & 3.59 & 3.39 \\
\hline P-Cymene & 0 & 1.75 & 1.32 & 4.83 & 2.31 & 2.78 & 2.56 \\
\hline beta-Pinene & 0 & 0.76 & 1.60 & 1.46 & 0.67 & 1.47 & 1.39 \\
\hline beta-myrcene & & 0.85 & 0.63 & 1.47 & 1.14 & 1.43 & 1.23 \\
\hline Alpha-terpinene & & 0.26 & 0.28 & 0.21 & 0.16 & 0.43 & 0.40 \\
\hline 3-Carene & & 0.93 & 0.74 & 1.71 & 0.75 & 1.13 & 1.00 \\
\hline Palatinol IC & & 4.54 & 5.72 & 2.05 & 3.65 & 2.86 & 3.04 \\
\hline Alpha-terpineolene & & 1.08 & 1.00 & 0.56 & 1.34 & 1.67 & 1.46 \\
\hline Terpinene-4-ol & & 1.19 & 1.78 & 1.45 & 1.29 & 1.27 & 1.41 \\
\hline Alpha-campholenol & & 2.28 & 2.60 & 1.65 & 3.32 & 1.68 & 2.69 \\
\hline Grandlure II & & 3.89 & 3.03 & 2.75 & 4.52 & 2.96 & 2.07 \\
\hline Bornyl acetate & & 1.91 & 2.85 & 3.02 & 3.74 & 3.45 & 3.38 \\
\hline Alpha- pinene & & 8.16 & 7.91 & 6.25 & 4.85 & 10.22 & 8.96 \\
\hline Eucalyptol & & 9.02 & 11.09 & 6.23 & 9.01 & 10.55 & 9.51 \\
\hline Linalool & & 6.37 & 6.47 & 7.76 & 6.88 & 5.73 & 6.31 \\
\hline Camphor & & 12.78 & 13.56 & 16.00 & 12.55 & 12.79 & 12.23 \\
\hline Endo-borneol & & 10.37 & 10.45 & 14.39 & 11.42 & 10.27 & 10.31 \\
\hline Alpha- terpineol & & 2.99 & 2.82 & 3.88 & 2.53 & 2.61 & 2.46 \\
\hline Cis-pinane & & 10.92 & 9.32 & 12.79 & 7.56 & 7.71 & 8.20 \\
\hline Trans-caryophyllene & & 2.56 & 2.77 & 3.73 & 1.98 & 1.90 & 3.06 \\
\hline Camphene & & 2.46 & 2.11 & 1.35 & 1.47 & 3.47 & 3.14 \\
\hline P-Cymene & & 2.50 & 1.84 & 0.87 & 2.31 & 2.06 & 1.78 \\
\hline beta-Pinene & 1 & 0.94 & 0.78 & 0.85 & 0.67 & 1.51 & 1.40 \\
\hline beta-myrcene & & 1.17 & 1.07 & 0.22 & 1.14 & 1.38 & 1.27 \\
\hline Alpha-terpinene & & 0.36 & 0.35 & 0.24 & 0.26 & 0.52 & 0.49 \\
\hline 3-Carene & & 1.30 & 1.11 & 0.21 & 0.75 & 1.20 & 1.14 \\
\hline Palatinol IC & & 3.74 & 5.45 & 5.82 & 3.65 & 4.38 & 3.58 \\
\hline Alpha-terpineolene & & 1.37 & 1.26 & 0.83 & 1.34 & 1.73 & 1.85 \\
\hline Terpinene-4-ol & & 1.41 & 1.33 & 1.73 & 1.29 & 1.32 & 1.22 \\
\hline Alpha-campholenol & & 1.76 & 2.19 & 2.88 & 3.32 & 2.22 & 2.98 \\
\hline Grandlure II & & 3.36 & 3.08 & 4.28 & 4.52 & 3.27 & 3.44 \\
\hline Bornyl acetate & & 2.59 & 2.34 & 2.20 & 3.74 & 3.68 & 4.02 \\
\hline
\end{tabular}


Table 6. Cont.

\begin{tabular}{|c|c|c|c|c|c|c|c|}
\hline \multirow[t]{4}{*}{$\overline{\text { Compound }}$} & \multirow{4}{*}{$\begin{array}{c}\mathbf{N} \\
(\mathrm{g} / \text { pot })\end{array}$} & \multicolumn{6}{|c|}{ Relative concentration of compound (\%) } \\
\hline & & \multicolumn{6}{|c|}{ Ascorbic acid (ppm) } \\
\hline & & \multicolumn{3}{|c|}{$1^{\text {st }}$ cut } & \multicolumn{3}{|c|}{$2^{\text {nd }}$ cut } \\
\hline & & $\overline{\mathbf{0}}$ & 50 & 100 & $\mathbf{0}$ & 50 & 100 \\
\hline Alpha- pinene & & 8.52 & 11.03 & 5.61 & 9.10 & 10.43 & 8.90 \\
\hline Eucalyptol & & 10.31 & 9.71 & 9.38 & 9.51 & 3.26 & 8.32 \\
\hline Linalool & & 5.34 & 6.84 & 6.69 & 5.68 & 4.07 & 5.91 \\
\hline Camphor & & 12.35 & 4.97 & 13.31 & 11.86 & 11.29 & 12.23 \\
\hline Endo-borneol & & 10.50 & 9.60 & 10.33 & 10.54 & 10.76 & 10.80 \\
\hline Alpha- terpineol & & 2.57 & 2.47 & 3.05 & 2.30 & 2.98 & 2.65 \\
\hline Cis-pinane & & 7.88 & 13.06 & 11.89 & 9.21 & 8.91 & 10.47 \\
\hline Trans-caryophyllene & & 3.35 & 2.07 & 2.97 & 1.71 & 2.74 & 2.41 \\
\hline Camphene & & 2.75 & 2.49 & 1.78 & 3.59 & 3.38 & 2.96 \\
\hline P-Cymene & 2 & 1.78 & 1.76 & 2.63 & 2.78 & 2.03 & 2.14 \\
\hline beta-Pinene & 2 & 0.75 & 0.75 & 0.86 & 1.47 & 1.31 & 1.42 \\
\hline beta-myrcene & & 0.89 & 0.97 & 1.17 & 1.43 & 1.23 & 1.31 \\
\hline Alpha-terpinene & & 0.34 & 0.29 & 0.40 & 0.43 & 0.43 & 0.57 \\
\hline 3-Carene & & 0.96 & 1.00 & 1.10 & 1.13 & 1.10 & 1.19 \\
\hline Palatinol IC & & 4.14 & 6.34 & 2.61 & 2.86 & 6.06 & 2.57 \\
\hline Alpha-terpineolene & & 1.24 & 1.11 & 1.70 & 1.67 & 1.54 & 1.85 \\
\hline Terpinene-4-ol & & 1.22 & 1.14 & 1.45 & 1.27 & 1.18 & 1.47 \\
\hline Alpha-campholenol & & 1.67 & 1.39 & 1.88 & 1.68 & 2.36 & 1.86 \\
\hline Grandlure II & & 2.43 & 2.54 & 3.28 & 2.96 & 3.95 & 1.83 \\
\hline Bornyl acetate & & 2.07 & 1.91 & 2.58 & 3.45 & 4.00 & 4.00 \\
\hline Alpha-pinene & & 8.47 & 4.37 & 6.30 & 8.80 & 10.95 & 9.15 \\
\hline Eucalyptol & & 10.43 & 7.19 & 2.44 & 9.75 & 12.70 & 8.61 \\
\hline Linalool & & 5.56 & 6.65 & 8.93 & 5.77 & 5.81 & 6.17 \\
\hline Camphor & & 13.67 & 15.88 & 14.77 & 12.44 & 14.73 & 11.33 \\
\hline Endo-borneol & & 10.46 & 13.03 & 14.80 & 10.90 & 10.90 & 10.17 \\
\hline Alpha- terpineol & & 2.87 & 3.84 & 4.09 & 3.04 & 2.25 & 2.49 \\
\hline Cis-pinane & & 11.44 & 13.05 & 10.79 & 8.93 & 8.45 & 9.98 \\
\hline Trans-caryophyllene & & 2.03 & 3.32 & 3.40 & 1.49 & 1.40 & 2.36 \\
\hline Camphene & & 2.60 & 2.25 & 2.14 & 3.39 & 3.31 & 3.34 \\
\hline P-Cymene & 2 & 3.27 & 0.69 & 0.38 & 2.56 & 1.80 & 2.48 \\
\hline beta-Pinene & 3 & 1.01 & 0.98 & 0.85 & 1.39 & 1.23 & 1.70 \\
\hline beta-myrcene & & 1.33 & 1.21 & 1.16 & 1.23 & 1.05 & 1.45 \\
\hline Alpha-terpinene & & 0.38 & 0.36 & 0.28 & 0.40 & 0.37 & 0.60 \\
\hline 3-Carene & & 1.49 & 1.21 & 0.95 & 1.00 & 0.90 & 1.24 \\
\hline Palatinol IC & & 2.96 & 5.57 & 3.61 & 3.04 & 6.36 & 2.30 \\
\hline Alpha-terpineolene & & 1.46 & 0.76 & 0.60 & 1.46 & 1.32 & 1.88 \\
\hline Terpinene-4-ol & & 1.45 & 1.64 & 2.07 & 1.41 & 1.17 & 1.36 \\
\hline Alpha-campholenol & & 1.76 & 2.85 & 1.34 & 2.69 & 1.43 & 1.89 \\
\hline Grandlure II & & 2.92 & 3.95 & 4.89 & 2.07 & 2.74 & 3.82 \\
\hline Bornyl acetate & & 2.29 & 3.56 & 2.69 & 3.38 & 3.64 & 3.88 \\
\hline
\end{tabular}


Zagazig J. Agric. Res., Vol. 45 No. (1) 2018

Table 7. Effect of nitrogen fertilization and ascorbic acid and their interaction on total chlorophyll (SPAD-502) of rosemary plant at two cuts during 2014 and 2015 seasons

\begin{tabular}{|c|c|c|c|c|c|c|c|}
\hline \multirow{2}{*}{$\begin{array}{c}\text { Nitrogen } \\
\text { (g/pot) } \\
(\mathbf{N})\end{array}$} & \multirow{2}{*}{$\begin{array}{l}\text { Ascorbic acid } \\
\text { (ppm) } \\
\text { (A) }\end{array}$} & \multicolumn{3}{|c|}{2014 season } & \multicolumn{3}{|c|}{2015 season } \\
\hline & & $1^{\text {st }}$ cut & $2^{\text {nd }}$ cut & Mean & $1^{\text {st }}$ cut & $2^{\text {nd }}$ cut & Mean \\
\hline \multirow{3}{*}{ 0 } & $\mathbf{0}$ & 29.23 & 28.47 & 28.85 & 27.60 & 29.25 & 28.43 \\
\hline & 50 & 34.03 & 36.13 & 35.08 & 33.35 & 39.00 & 36.18 \\
\hline & 100 & 37.80 & 37.23 & 37.52 & 38.00 & 40.75 & 39.38 \\
\hline \multirow[t]{2}{*}{ Mean } & & 33.69 & 33.94 & 33.82 & 32.98 & 36.33 & 34.66 \\
\hline & $\mathbf{0}$ & 35.12 & 33.83 & 34.48 & 32.11 & 33.05 & 32.58 \\
\hline \multirow[t]{2}{*}{1} & 50 & 36.72 & 36.10 & 36.41 & 35.00 & 40.45 & 37.73 \\
\hline & 100 & 39.13 & 37.63 & 38.38 & 38.50 & 41.50 & 40.00 \\
\hline \multirow[t]{2}{*}{ Mean } & & 36.99 & 35.86 & 36.42 & 35.20 & 38.33 & 36.77 \\
\hline & 0 & 38.73 & 36.17 & 37.45 & 40.40 & 35.85 & 38.13 \\
\hline \multirow[t]{2}{*}{2} & 50 & 39.10 & 37.83 & 38.47 & 39.45 & 42.40 & 40.93 \\
\hline & 100 & 41.40 & 39.50 & 40.45 & 42.80 & 42.55 & 42.68 \\
\hline \multirow[t]{2}{*}{ Mean } & & 39.74 & 37.83 & 38.79 & 40.88 & 40.27 & 40.58 \\
\hline & $\mathbf{0}$ & 40.23 & 38.93 & 39.58 & 40.30 & 40.50 & 40.40 \\
\hline \multirow[t]{2}{*}{3} & 50 & 42.33 & 42.13 & 42.23 & 42.30 & 43.00 & 42.65 \\
\hline & 100 & 42.42 & 43.00 & 42.71 & 42.14 & 43.20 & 42.67 \\
\hline Mean & & 41.66 & 41.36 & 41.51 & 41.58 & 42.23 & 41.91 \\
\hline \multirow[t]{2}{*}{ Grand mean } & & 38.02 & 37.25 & 37.63 & 37.66 & 39.29 & 38.48 \\
\hline & $\mathbf{0}$ & 35.83 & 34.35 & 35.09 & 35.10 & 34.66 & 34.88 \\
\hline \multirow[t]{2}{*}{ Mean of ascorbic } & 50 & 38.05 & 38.05 & 38.05 & 37.53 & 41.21 & 39.37 \\
\hline & 100 & 40.19 & 39.34 & 39.77 & 40.36 & 42.00 & 41.18 \\
\hline \multicolumn{8}{|l|}{ LSD at $5 \%$} \\
\hline Nitrogen $(\mathbf{N})$ & & 1.90 & 2.99 & 2.80 & 0.91 & 2.37 & 2.42 \\
\hline Ascorbic acid (A) & & 1.43 & 2.74 & 1.49 & 0.80 & 1.89 & 0.99 \\
\hline $\mathbf{N} \times \mathbf{A}$ & & 2.85 & 3.49 & 2.23 & 1.60 & 2.78 & 1.97 \\
\hline
\end{tabular}


Table 8. Chemical composition of rosemary plant as affected by nitrogen fertilization and ascorbic acid treatments

\begin{tabular}{|c|c|c|c|c|c|c|c|c|c|}
\hline \multirow{3}{*}{$\begin{array}{c}\text { Chemical constituent } \\
\text { (\%) }\end{array}$} & \multirow{3}{*}{$\underset{(\mathrm{g} / \text { pot })}{\mathbf{N}}$} & \multicolumn{8}{|c|}{ Ascorbic acid (ppm) } \\
\hline & & \multicolumn{3}{|c|}{$1^{\text {st }}$ cut } & \multirow[t]{2}{*}{ Mean } & \multicolumn{3}{|c|}{$2^{\text {nd }}$ cut } & \multirow[t]{2}{*}{ Mean } \\
\hline & & $\mathbf{0}$ & 50 & 100 & & $\mathbf{0}$ & 50 & 100 & \\
\hline \multirow{4}{*}{ Total carbohydrates } & $\mathbf{0}$ & 14.20 & 16.40 & 18.10 & 16.23 & 11.60 & 13.30 & 14.40 & 13.10 \\
\hline & 1 & 15.00 & 17.60 & 19.30 & 17.30 & 14.40 & 17.70 & 19.60 & 17.23 \\
\hline & 2 & 16.60 & 18.70 & 22.50 & 19.27 & 17.20 & 19.10 & 21.40 & 19.23 \\
\hline & 3 & 17.70 & 20.10 & 26.50 & 21.43 & 18.50 & 21.50 & 23.40 & 21.13 \\
\hline \multirow[t]{2}{*}{ Mean } & & 15.88 & 18.20 & 21.60 & 18.56 & 15.43 & 17.90 & 19.70 & 17.68 \\
\hline & $\mathbf{0}$ & 1.07 & 1.16 & 1.45 & 1.23 & 1.27 & 1.41 & 1.67 & 1.45 \\
\hline \multirow{3}{*}{ Total N } & 1 & 1.16 & 1.42 & 1.58 & 1.39 & 1.44 & 1.67 & 1.93 & 1.68 \\
\hline & 2 & 1.35 & 1.61 & 1.71 & 1.56 & 1.74 & 1.87 & 2.03 & 1.88 \\
\hline & 3 & 1.61 & 1.65 & 2.00 & 1.75 & 1.87 & 1.96 & 2.09 & 1.97 \\
\hline \multirow[t]{2}{*}{ Mean } & & 1.30 & 1.46 & 1.69 & 1.48 & 1.58 & 1.73 & 1.93 & 1.75 \\
\hline & 0 & 0.12 & 0.15 & 0.22 & 0.16 & 0.14 & 0.17 & 0.24 & 0.18 \\
\hline \multirow{3}{*}{ Total P } & 1 & 0.14 & 0.21 & 0.23 & 0.19 & 0.15 & 0.18 & 0.25 & 0.19 \\
\hline & 2 & 0.17 & 0.21 & 0.24 & 0.21 & 0.15 & 0.19 & 0.25 & 0.20 \\
\hline & 3 & 0.23 & 0.24 & 0.26 & 0.24 & 0.21 & 0.23 & 0.31 & 0.25 \\
\hline \multirow[t]{2}{*}{ Mean } & & 0.17 & 0.20 & 0.24 & 0.20 & 0.16 & 0.19 & 0.26 & 0.21 \\
\hline & 0 & 0.94 & 1.05 & 1.34 & 1.11 & 1.02 & 1.10 & 1.15 & 1.09 \\
\hline \multirow{3}{*}{$\mathbf{K}$} & 1 & 1.16 & 1.26 & 1.42 & 1.28 & 1.18 & 1.26 & 1.26 & 1.23 \\
\hline & 2 & 1.18 & 1.49 & 1.57 & 1.41 & 1.26 & 1.34 & 1.42 & 1.34 \\
\hline & 3 & 1.34 & 1.49 & 1.72 & 1.52 & 1.34 & 1.42 & 2.10 & 1.62 \\
\hline Mean & & 1.16 & 1.32 & 1.51 & 1.33 & 1.20 & 1.28 & 1.48 & 1.32 \\
\hline
\end{tabular}




\section{REFERENCES}

Adams, R.P. (1995). Identification of essential oil components by gas chromatography mass spectroscopy. Allured, Carol, Stream, Illions, USA, 1-2.

AOAC (1990). Official Methods of Analysis, $15^{\text {th }}$ Ed., Published by Association of Official Analytical Chemists, Washington, DC, USA, 684.

Badawy, E.M., E.I. El-Maadawy and A.A.M. Heikal (2009). Effect of nitrogen, potassium levels and harvesting date on growth and essential oil productivity of Artemisia annua L. plant. Proc. $4^{\text {th }}$ Conf. on Recent Technol. in Agric., Chall. Agric. Modernization", 3 -5 November, Giza, Egypt, 600-615.

Banon, S., L. Mendez and E. Almela (2012). Effects of dietary rosemary extract on lamb spoilage under retail display conditions. Meat Sci., 90 (3):579-583.

Baranauskienne, R., P.R. Venskutonis, P. Viskelis and E. Dambrausiene (2003). Influence of nitrogen fertilizer on the yield and composition of thyme (Thymus vulgaris). J. Agric. Food Chem., 51: 7751-7758.

Blokhina, O., E. Virolainen and K.V. Fagerstedt (2003). Antioxidant, oxidative damage and oxygen deprivations stress. A Rev. Ann. Bot., 91: 179-194.

British Pharmacopoeia (1963). Determination of volatile oils in drugs. The Pharmaceutical Press, 17 Bloomsbury Square, WCI, London, 213.

Cheung, S. and J. Tai (2007). Anti-proliferative and antioxidant properties of rosemary (Rosmarinus officinalis). Oncol Rep., 17 (6): 1525-1531

Dubois, M., K.A. Gilles, J.K. Hamilton, P.A. Repers and F. Smith (1956). Colorimetric method for determination of sugars and related substances. J. Anal. Chem., 28 (3): 350-356.

El-Kobisy, D.S., K.A. Kady, R.A. Medani and R.A. Agamy (2005). Response of pea plant (Pisum sativumL.) to treatment with ascorbic acid. Egypt. J. Appl. Sci., 20:36-50.
El-Quesni, F.E.M., N.G. Abd El-Aziz and M.M. Kandil (2009). Some studies on the effect of ascorbic acid and $\alpha$ - tocopherol on the growth and some chemical composition of Hibiscus rosa sineses L. at Nubaria. Ozean J. Appl. Sci., 2 (2):159-167.

Farooq, M., A.B. Ali and A.C. Sardar (2013). Application of Allelopathy in Crop Production. Int. J. Agric. and Biol., 15: 13671378.

Freed, R.S.P., S. Einensmith, S. Gutez, D. Reicosky, V.W. Smail and P. Wolberg (1989). MSTAT-C analysis of agronomic research experiments. Michigan Univ. East Lansing, USA.

Genena, A.K., H. Hense, A. Smania and S.M. de Souza (2008). Rosemary (Rosmarinus officinalis)- a study of the composition, antioxidant and antimicrobial activities of extracts obtained with supercritical carbon dioxide, Ciencia e Tecnologia de Alimentos, 28 (2): 463-469.

Gomez, K.A. and A.A. Gomez (1984). Statistical Procedures for Agricultural Research. $2^{\text {nd }}$ Ed. John Wily and Sons. Inc. New York, USA, 97-107.

Hendawy, S.F. and A.A. Ezz El-Din (2010). Growth and yield of Foeniculum vulgare var.azoricum as influenced by some vitamins and amino acids. Ozean J. Appl. Sci., 3(1): $113-123$.

Issac, R.A. and J.D. Kerber (1971). Atomic absorption and flamephotometry: techniques and Uses in soil, plant and water analysis. In instrumental methods for analysis of soil and plant tissue. Soil Sci. Soc. Ame., Madison, WI, USA, 17-37.

Jackson, M.L. (1967). Soil Chemical Analysis. Printice, Hall of India, 144-197.

Jiang, Y., N. Wu, Y.J. Fu, W. Wang, M. Luo, C.J. Zhao, Y.G. Zu and K.L. Liu (2011). Chemical composition and antimicrobial activity of the essential oil of rosemary. Environ. Toxicol Pharmacol., 32 (1):63-68.

Khalil, S.E., N.G. Abd El-Aziz and B.H. Abou Leila (2010). Effect of water stress, ascorbic acid and spraying time on some 
morphological and biochemical composition of Ocimum basilicum plant. J. Ame. Sci., 6 (12): 33-44.

Martínez, A.L., M.E. Gonzalez-Trujano, F. Pellicer, F.J. Lopez-Munoz and A. Navarrete (2009). Antinociceptive effect and GC/MS analysis of Rosmarinus officinalis $\mathrm{L}$. essential oil from its aerial parts. Planta Med., 75 (5):508-511.

Min, S.Y., A.R.M. Tawaha and K.D. Lee (2005). Effects of ammonium concentration on the yield, mineral content and active terpene components of Chrysanthemum coronarium L. in a hydroponic system. Res. J. Agric. Biol. Sci., 1 (2): 170-175.

Miguel, M.G., C. Guerrero, H. Rodrigues and J. Brito (2007). Essential oils of Rosmarinus officinalis L., effect of harvesting dates, growing media and fertilizers. Proc. of the $3^{\text {rd }}$ IASME/WSEAS Int. Conf. on Energy, Environ., Ecosystems and Sustainable Dev., Agios Nikolaos, Greece, 65-70.

Moghtader, M., H. Salari and A. Farahmand (2011). Evaluation of the antifungal effects of rosemary oil and comparison with synthetic borneol and fungicide on the growth of Aspergillus flavus. J. Ecol. and the Nat. Environ., 3(6): 210-214.

Moreno, S., T. Scheyer, C.S. Romano and A.A. Vojnov (2006). Antioxidant and antimicrobial activities of rosemary extracts linked to their polyphenol composition. Free Radical Res., 40: 223-231.

Netto, A.T., E.J. Campostrini, G. Oliveira and S.R.E. Bressan (2005). Photosynthetic pigments, nitrogen, chlorophyll a fluorescence and SPAD 502 reading in coffee leaves. Scientia Hort., 104 (2): 199-209.

Nieto, G, P. Di'az, S. Baño'n and M.D. Garrido (2010). Dietary administration of ewe diets with a distillate from Rosemary leaves (Rosmarinus officinalis L.): influence on lamb meat quality. Meat Sci., 84:23-29.

Nikee, E., A. Pazoki and H. Zahedi (2014). Influences of ascorbic acid and gibberellin on alleviation of salt stress in summer savory (Satureja hortensis L.). Int. J. Biosci., 5 (4): 245-255.
Oluwatuyi, M., G.W. Kaatz and S. Gibbons (2004). Antibacterial and resistance modifying activity of Rosmarinus officinalis. Phytoch., 65 (24): 3249-3254.

Puttanna, K., E.V.S.P. Rao, R. Singh and S. Ramesh (2010). Influence of nitrogen and potassium fertilization on yield and quality of rosemary in relation to harvest number. Communications in Soil Sci. and Plant Anal., 41:190-198.

Said-Al Ahl, H.A.H., H.S. Ayad and S.F. Hendawy (2009). Effect of potassium humate and nitrogen fertilizer on herb and essential oil of oregano under different irrigation intervals. J. Appl. Sci., 2(3): 319-323.

Sharabani, H., E. Izumchenko, Q. Wang, R. Kreinin, M. Steiner, Z. Barvish, M. Kafka, Y. Sharoni, J. Levy, M. Uskokovic, G.P. Studzinski and M. Danilenko (2006). Cooperative antitumor effects of vitamin D3 derivatives and rosemary preparations in a mouse model of myeloid leukemia. Int. J. Cancer, 118 (12): 3012-3021.

Singh, M. and K. Wasnik (2013). Effect of vermicompost and chemical fertilizer on growth, herb, oil yield, nutrient uptake, soil fertility, and oil quality of rosemary. Communications in Soil Sci. and Plant Anal., 44 (18): 2691-2700.

Smirnoff, N. and G.L. Wheeler (2000). Ascorbic acid in plants: biosynthesis and function. Crit. Rev Biochem. Mol. Biol., 35: 291-314.

Stutte, G.W. (2006). Process and product: recirculation hydroponics and bioactive compounds in a controlled environment. Hort. Sci., 41: 526-530.

Talaat, N.B. (2003). Physiological studies on the effect of salinity, ascorbic and putrescine of sweet pepper plant. Ph.D. Thesis, Fac. Agric., Cairo Univ., Egypt.

Tarraf, S.A., K.G. El-Din and L.K. Balbaa (1999). The response of vegetative growth, essential oil of lemongrass (Cymbopogon citratus Hort.) to foliar application of ascorbic acid, nicotenamid and some micronutrients. Arab Univ. J. Agric. Sci., 7: 247- 259.

Tsai, C.W., C.Y. Lin, H.H. Lin and J.H. Chen (2011). Carnosic acid, a rosemary phenolic 
compound, induces apoptosis through reactive oxygen species-mediated p38 activation in human neuroblastoma IMR-32 cells. Neurochem Res., 36 (12): 2442-2451.

Yi, W. and H.Y. Wetzstein (2010) Biochemical, biological and histological evaluation of some culinary and medicinal herbs grown under greenhouse and field conditions. J. Sci. Food Agric., 90 (6): 1063-1070.

Zhang, Y. (2013). Ascorbic Acid in Plants: Biosynthesis, Regulation and Enhancement. Publisher: New York: Springer.

\section{تأثثير التسميد النيتروجينى وحامض الأسكوربيك على النمو ومحتوى الزيت الطيار والمحتوى الكيميائي لنبات الحصالبان \\ آمال عبد الخالق محمد هيكل - سامية سامي حلمي \\ قسم بساتين الزينة ـ كلية الزر اعة - جامعة القاهرة - مصر فئر}

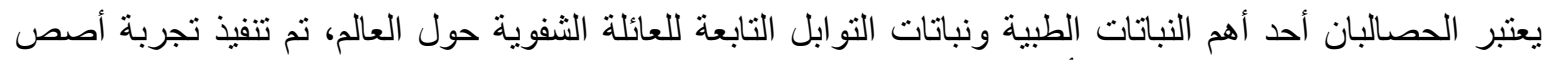

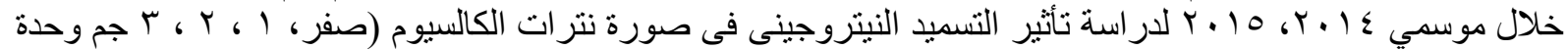

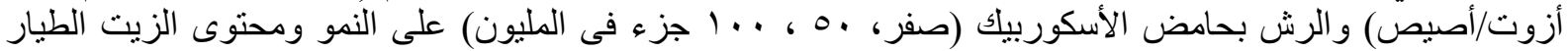

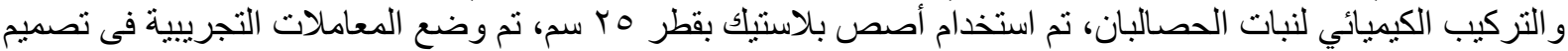

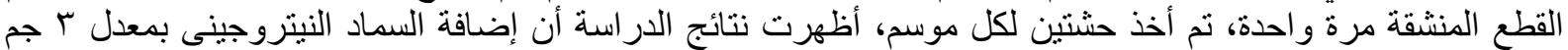

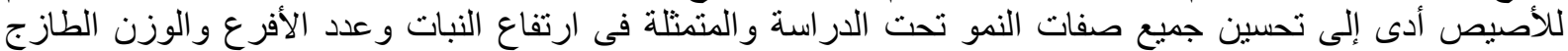

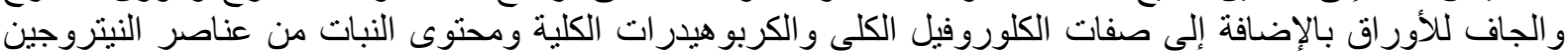

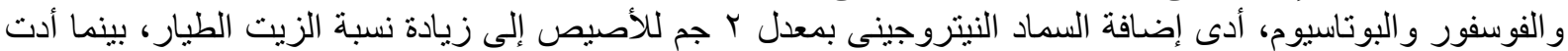

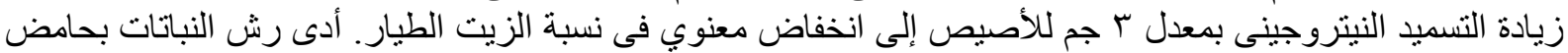

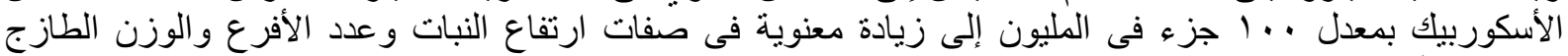

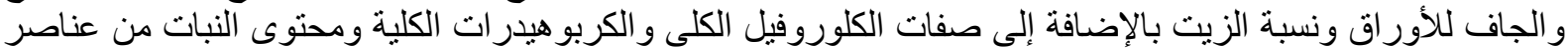

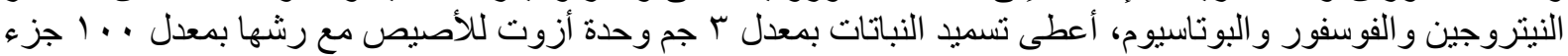

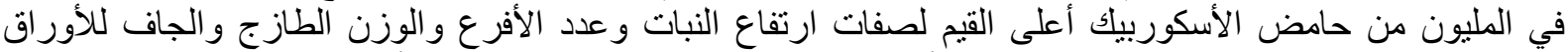

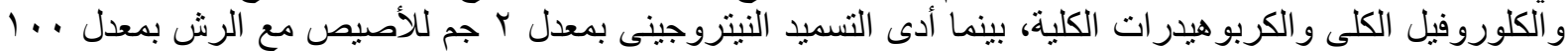

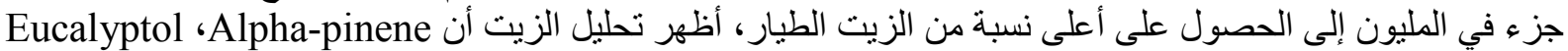
Cis-pinane ، Endo-borneol ، Camphor ، Linalool الدر اسة للحشتين الأولى و الثنانية.

أستاذ الزينة و النباتات الطبية و العطرية ـ كلية الزر اعة - جامعة القاهرة. أستاذ الزينة و النباتات الطبية و العطرية ـ كلية الزر اعة الزية - جامعة الزقازيق. 